This article was downloaded by: [130.132.123.28]

On: 23 December 2014, At: 21:33

Publisher: Routledge

Informa Ltd Registered in England and Wales Registered Number: 1072954

Registered office: Mortimer House, 37-41 Mortimer Street, London W1T

3J H, UK

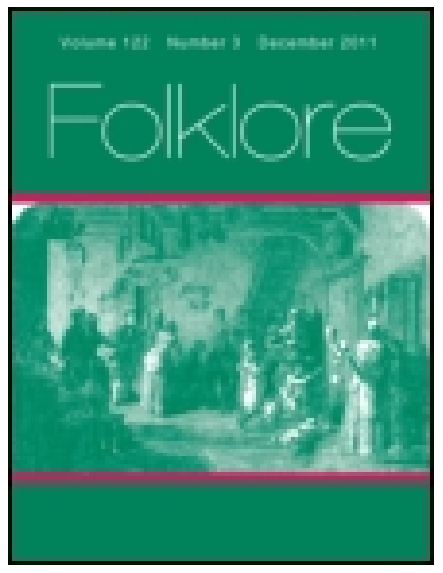

\title{
Folklore
}

Publication details, including instructions for authors and subscription information:

http:// www. tandfonline.com/loi/ rfol20

\section{Christs Half-Dole: An East Anglian Fishing Custom}

W. B. Gerish

Published online: 14 Feb 2012.

To cite this article: W. B. Gerish (1898) Christs Half-Dole: An East Anglian Fishing Custom, Folklore, 9:3, 245-250, DOI: 10.1080/0015587X.1898.9720458

To link to this article: http:// dx. doi. org/ 10.1080/0015587X.1898.9720458

\section{PLEASE SCROLL DOWN FOR ARTICLE}

Taylor \& Francis makes every effort to ensure the accuracy of all the information (the "Content") contained in the publications on our platform. However, Taylor \& Francis, our agents, and our licensors make no representations or warranties whatsoever as to the accuracy, completeness, or suitability for any purpose of the Content. Any opinions and views expressed in this publication are the opinions and views of the authors, and are not the views of or endorsed by Taylor \& Francis. The accuracy of the Content should not be relied upon and should be independently verified with primary sources of information. Taylor and Francis shall not be liable for any losses, actions, claims, proceedings, demands, costs, expenses, damages, and other liabilities whatsoever or howsoever caused arising directly or indirectly in connection with, in relation to or arising out of the use of the Content.

This article may be used for research, teaching, and private study purposes. Any substantial or systematic reproduction, redistribution, reselling, loan, sub-licensing, systematic supply, or distribution in any form to anyone is 
expressly forbidden. Terms $\&$ Conditions of access and use can be found at http://www.tandfonline.com/page/terms-and-conditions 


\section{CHRIST'S HALF-DOLE : AN EAST ANGLIAN FISHING CUSTOM.}

By W. B. Grrish

THE ancient custom of paying a tribute to the Church on the harvest of the sea comes, I think, within the domain of the folklorist. It was never a tithe, correctly speaking, as by law fish taken in the sea or river were not titheable, although if taken in enclosed water they were. Originally, therefore, a free-will offering-the origin of which dates from the earliest times, as old, perhaps, as Christianity itself, or in another form possibly even older, and given by the fisher-folk at Yarmouth, Gorleston, and Lowestoft, with the idea of securing a safe voyage and heavy catch of fish-it became in course of time a custom, and was afterwards assumed to be a right which the Church, both Catholic and Protestant, demanded and enforced. At one time it must have formed no inconsiderable item in the value of the livings. In the reign of Edward III., the half-dole at Yarmouth realised the large sum of 700 marks (about $\mathrm{f466}$ ), but in the reign of Henry VIII. it had fallen as low as 60 marks.

Mr. J. W. de Caux in his book on the Herring and Merring-Fishery states (p. 98-9):

"From time to time efforts were made to shake off this incubus, and as late as 1845 the Rev. F. Cunningham, vicar of Lowestoft, summoned a fisherman named John Roberts ' for having refused or neglected to pay tithes for his fish.' The case was argued for the defendant by Mr. J. H. Tillett of Norwich, who contended that the 'tithe did not arise,' as was stated in the information, 'in the parish of Lowestoft, but in the sea,' and that therefore, as it was neither legal nor just, it could not be enforced.' The magistrates, however, found for the complainant, and made an order for 
10s. $3^{d}$. and Ios. costs. Whether this order was obeyed or not, I cannot say; but since then, as far as I have been able to learn, the custom has been more honoured in the breach than in the observance. I have been told that the custom was enforced at Great Yarmouth until a fisherman, happening to have, a tenth child, took it to the vicarage in the vain hope that the vicar would adopt it. "Whilst this chrstom was enforced special religious services were beld during the herring season for the spiritual; welfare and earthly prosperity of the fishermen; and. from an old manuscript I-learn that the proper Psalms and Lessons in use at such services were as follows: Psalms, the whole of the $45^{\text {th }}$, verses 19 to $4 \mathrm{I}$ of the .78 th, from verse 24 to the end of the ro4th, verses 23 to 32 of the Iopth; Lessons, Genesis 1st, 20 to 24,2 Kings 7 th, 1,2 , and 20, Habbakuk 3 rd, 17 and 18 , Matthew 8 th, 23 to 27 , Luke 5 th, 4 to 10, John 6th, 26 and 27. Before the Reformation it was usual for the priest to 'give a blessing to the fishing yearly." "

It may be mentioned that the half-dole which was claimed by the town 'of Great Yarmouth (this was enforced by a bye-law dating from 1484 and assigned to the support of the haven and pier) ceased to be collected in 1824 , and this evidently-proved a.death-blow to the Church's half-dole, as it did not long survive after this. Mr. Lupson, the parish clerk, believesra share of the catch is still called the "Vicar's share," but this share never reaches him, it is merely.a Burvival.

The above quotation from Mr. de Caux's work was written in:I88I; and some five or six years afterwards 2 circular was sent out by the then churchwardens of $S t$. Nicholas, Great Yarmouth, which contained the following paragraph: "The vicar is (in lieu of an ancient tithe on the fishing) alone entitled to receive an Easter. offering from every inhabitant of the town, whether attending divine worship at the parish church or not." 
Án interèsting discussion on the above arose af the vestry meeting, in which Mr. de Caux took an active part. He stated that he knew that in the olden time there used to be what was called "Christ's half-dole," but that was not on fish generally but only on herring (Mr. Thomas Hammond a witness at the British Channel Fisheries Commission, spécified màckērel ând herring). That, however, fell into desuetude fifty years ago; but in 1858 the then mayor, Mr. Robert Steward, believing that the old custom was legal, desired to revive it: The custom was that the first-fruits of the frishing should be presented to the mayor. Mr. Steward thought there was a legal act for that, and he knew that he took légal advice in the matter. With"regard to Christ's half-dole, it was simply a free-will offering which became a custom, but it was entirely dropped and there was no legal enactment for it. In the paragraph it was stated that the tithe was payable by every individual in the town. He had pointed out that if there was an ancient tithe it was only payable by the fishermen; but if the paragraph was correct then every individual in the town was liable to pay those Easter offerings, and that meant not only the ratepayers but strangers who happened to be residing there for a short time. "He held that it was an improper and incoirrect stafement to make, and strongly objected to it.

He went on to state that while Church-rates were in existence nothing was said about "Christ's half-dole;" the first he heard of it was about fourteen years ago. After some further remarks the vicar replied, stating that his predecessors, going back as far, he thought, as Dr. Pellew (183I-1844) as vicars of Yarmouth appeared, whether legally or not, to have received something in connection with the fishing. As late as -Canon Nevill's time (18591874) he certainly did receive something per boat, the owners of which merely by ancient custom it might be, apart from any legal claim, paid to the vicar a guinea or something of that sort. After some further discussion it 
was decided to alter the wording of the paragraph in future circulars to avoid the possible misconception.

The present vicar, the Rev. J. E. Rogers, to whom I wrote, was unable to give me any information, but kindly asked the parish clerk to write me, and the latter tells me that nothing is now paid.

In Statistics of the Fisheries of Yarmouth and Loxestoft, by George Nall, 1866, the witness Hammond, previously mentioned, stated :

"We pay tithe on both herring and mackerel. The clergymen value the herring at so much per last, according to their number. Persons go round and ascertain the number each boat has caught, value them, and deduct a certain proportion for the boat's expense; the remainder is divided into eighty shares" (termed "doles;" the statutes and ordinances of the town regulated these from very early times) " of which he takes one. It amounts to between $£_{2}$ and $£_{3}$ each boat. The Yorkshire - boats pay nothing."

With reference to the adjoining parish of Gorleston, Dr. J. Bately has kindly sent me a copy of a Terrier dated 1827 which says :

"Southtown is consolidated to Gorleston with Westtown where all the Tythes both great and small belong solely to the vicar of Gorleston and are constantly paid to him or his tenants in kind or compounded for. Tythe of fish taken of the sea is by custom due to the vicar, viz., for every boat occupied or employed in the herring fishery and the owners whereof live within the parish ros. $6 d$., and for boats employed in the mackerel fishery a consideration likewise hath always been paid to the vicar in proportion to the quantity taken."

This customary payment has also long ceased, Dr. Bately tells me. It was probably discontinued at the same time as at Yarmouth.

The vicar of Lowestoft, the Rev. W. J. Lawrance, has 
kindly sent me the following note on the custom therecommunicated by F. W. Longe, Esq., of that town :

"The earliest record which we are aware of, referring to the tithe of fish, is an account of a valuation of the living in 1567 (10 Eliz.), in which it is stated that in the time of Henry VIII., before the dissolution of the monasteries, this tithe amounted to $£_{14}$, being $\ell_{1}$ received from each of the fourteen ships going to Iceland for the cod and ling fishing.

"It is stated in the same proceedings that these receipts had fallen to $\ell_{I}$ in 1567 , when the ships going to Iceland had been reduced to that number.

"In a private account of this tithe, written by the vicar (the Rev. J. Tanner) in 1785 , it is stated that the fishery so declined after ${ }^{1567}$ that no tithe of fish was claimed, and the income of the vicars was supplemented for many years by voluntary contributions, and thus when the fishing began to revive the vicars still abstained for some years from claiming the tithe from fear of checking the voluntary contributions.

"During the eighteenth century the fish-tithe was again received from the owners of ships employed in the herring and mackerel fishing. The vicar's claim, as supported by ancient custom both at Lowestoft and Yarmouth, was for a half-dole or half-share in the division of the produce of each fishing voyage; this claim as regards the herring fishery seems to have been privately compounded for by a payment of 10s. a year for each ship going to sea. The tithe from the mackerel fishing was still received as a half-dole, but it seems that the shipowners were in the habit of varying the number of doles or shares into which the produce was divided, so that the value of the vicar's half-dole was-reduced to the three-hundredth part of the total sum divided.

"From a statement of the value of the living in 183 I by the then vicar, the amount received in that year for fish-tithe was $£ 47$ 17s. $4 \frac{1}{2} d$. In 1845 the legality of the claim of tithe 
of fish being dišputed, the vicar, the Rev́. Francis Cunningham, had the question tried before the local imagistrates. He won his case, but the proceedings to enforce payment caused so much opposition and bad feeling that the vicar thought it his duty. not to follow the matter up, and he appears to have abandoned all claim for fish-tithe, either from the herring or mackerel fishery: Since this time and then, a large fishing trade, the trawl fishing, has grown up at Lowestoft, from which no claim for a fish-tithe was ever made."

It would be interesting to learn if this custom prevailed, as I am of opinion it did, at other fishing towns in England. 